Alina Jurcewicz

\title{
Warunki funkcjonowania rolnictwa w świetle umów międzynarodowych
}

\section{Wprowadzenie}

Wprowadzając wspólny rynek produktów rolnych, traktaty Wspólnot zliberalizowały na obszarze państw członkowskich handel tymi produktami. Jednakże proces ten został istotnie ograniczony instrumentami wspólnej polityki rolnej, uzależniającymi produkcję od jej historycznych rozmiarów oraz geograficznego rozmieszczenia, a także poprzez wprowadzenie systemu narodowych kwot produkcyjnych. W tej sytuacji, ale też z powodów występujących „,na zewnątrz” EU, inicjatywy takie podejmowane były poza Wspólnotą - na forum GATT (General Agreement on Tariffs and Trade - Układ Ogólny w sprawie Taryf Celnych i Handlu), obecnie zaś Światowej Organizacji Handlu (WTO - World Trade Organization, która zastąpiła w 1995 r. GATT ${ }^{1}$ ). Problematyka międzynarodowego handlu rolnego i niektórych aspektów wewnętrznej polityki rolnej została po raz pierwszy objęta wielostronnym porozumieniem w ramach Aktu końcowego Rundy Urugwajskiej GATT (The Agreement on Agriculture - Porozumienie w sprawie rolnictwa²), które jest głównym przedmiotem niniejszego opracowania.

Runda Urugwajska oceniana jest jako historyczne osiągnięcie i to zarówno w odniesieniu do rolnictwa, jak i innych dziedzin gospodarki ${ }^{3}$. Istotnie wzmacniając postanowienia GATT w sprawach rolnych, kształtować miała przyszłą politykę rolną państw członkowskich nowo utworzonej Światowej Organizacji Handlu (WTO). Pomimo nakreślenia - w deklaracji z Punta del Ester - ambitnych celów oraz osiągnięcia znaczącego konsensusu podczas negocjacji, trzeba przyznać, że Porozumienie w sprawie rolnictwa stanowi zaledwie pierwszy krok w kierunku reformy han-

Zob. A. Jurcewicz, Kształtowanie przyszłej polityki rolnej Unii Europejskiej na tle polityki gospodarczej, (w:) Wspólna polityka rolna Unii Europejskiej i jej wpływ na region zamojski, Zeszyty Naukowe Wyższej Szkoły Humanistyczno-Ekonomicznej im. J. Zamojskiego, Zamość 2005, s. 15 i nast.; A. Jurcewicz, Wsparcie rolnictwa w świetle porozumień międzynarodowych (w:) Prawo w XXI wieku, Księga pamiątkowa 50-lecia Instytutu Nauk Prawnych Polskiej Akademii Nauk, pod red. W. Czaplińskiego, Scholar, Warszawa 2006, s. 323 i nast. 
dlu międzynarodowego oraz systemów wsparcia rolnictwa. Program reform zakładał przyjęcie konkretnych zobowiązań w celu zwiększenia dostępu do rynku rolnego oraz ograniczenia krajowych i eksportowych subsydiów, co - zgodnie z preambułą - doprowadzić miało do „znacznych ograniczeń wsparcia i ochrony w uzgodnionym okresie czasu". Uzgodniony okres realizacji (zgodnie z art. 1(f)) trwać miał sześć lat (dziesięć lat dla krajów rozwijających się), poza przypadkiem (art. 13) tzw. klauzuli pokoju (Peace Clause), ograniczającej możliwość wnoszenia sporów przez dziewięć lat. Inaczej niż Układ GATT, który nie określił definicji produktu rolnego, załącznik 1 do Porozumienia stanowi, że stosuje się do wszystkich produktów wymienionych w rozdziałach 1-24 the Harmonised System (HS), poza rybami i produktami rybnymi oraz pewnymi innymi produktami, które zostały wyszczególnione.

Jak dotąd, handel rolny pomiędzy państwami rozwiniętymi odbywa się na wysoce sztucznych zasadach, odzwierciedlając system wsparcia rolnictwa na wewnętrznych rynkach tych państw. Bez wątpienia jest to dziedzina, w której państwa rozwinięte nie wyraziły zgody na swobodne działanie sił rynku. Odwołując się do danych podawanych przez $\mathrm{OECD}^{4}$ (Organization for Economic Cooperation and Development - Organizacja Współpracy Gospodarczej i Rozwoju), które porównują wsparcie dla producentów rolnych w przeliczeniu na równowartość dotacji dla producenta, bez względu na to, czy jest to wsparcie cenowe, czy wypłata dotacji jako takich, średni poziom wsparcia w państwach członkowskich OECD w roku 1999 stanowił 40\%, przy niewiele różniącym się poziomie 47\% we Wspólnocie. To paradoks, że w latach 1986-1988 - przed Rundą Urugwajską, która doprowadziła do podpisania wspomnianego powyżej porozumienia w sprawie rolnictwa - średnia w OECD wynosiła tyle samo, tj. 40\%, natomiast średnia we Wspólnocie wynosiła 44\%, a zatem była niższa. W roku 1999 średnia dla Stanów Zjednoczonych wynosiła 24\% (25\% w latach 1986-1988), tj. była nieznacznie niższa, dla Japonii 65\% (67\%), a dla Szwajcarii 73\% (73\%). Kwota dotacji na jednego rolnika, wynosząca we Wspólnocie 17 tys. USD, była trochę niższa od średniej OECD w wysokości 20 tys. USD i niższa niż w Stanach Zjednoczonych, gdzie wynosiła 21 tys. USD na rolnika - różnica zapewne odzwierciedla różnice w wielkości jednostek produkcyjnych pomiędzy Wspólnotą a Stanami Zjednoczonymi.

Do sytuacji tej doszło w wyniku nałożenia się wsparcia na rynku wewnętrznym (bez znaczenia jest, czy na rzecz producentów czy produktów), ochrony przed importem oraz wsparcia eksportu, a handel rolny widziany na tym tle w GATT zawsze traktowano w sposób szczególny. Już na samym początku funkcjonowania GATT (w roku 1951) Stany Zjednoczone znowelizowały swoje ustawodawstwo rolne, aby umożliwić wprowadzenie kontyngentów i opłat licencyjnych przy imporcie produktów rolnych mogących zakłócić programy cenowego wsparcia na rynku we- 
wnętrznym, a chcąc wprowadzić tę nowelizację w życie, ubiegały się o zwolnienie ze zobowiązań GATT, które w końcu otrzymały (w 1955 roku). Jako uzasadnienie podano, że charakter krajowych programów wsparcia rolnictwa przyciągał tak wyjątkowy wolumen importu, że miał on niekorzystny wpływ na te programy ${ }^{5}$. Można chyba powiedzieć, że zwolnienie to nadało ton przyszłym regulacjom handlu rolnego 6 .

Jakkolwiek zresztą było, należy zauważyć, że wsparcie produktów rolnych i producentów rolnych na wewnętrznym rynku, ochrona przed importem i wsparcie eksportu nie są jako takie zakazane przez GATT. Nie są także zakazane na mocy porozumienia Rundy Urugwajskiej w sprawie rolnictwa. Porozumienie to wymaga jedynie, aby zostały one zredukowane zgodnie ze zobowiązaniami podjętymi przez sygnatariuszy. Stanowi jednak, że pewne formy wsparcia mogą w bardziej prawdopodobny sposób wywołać zakłócenia w handlu w porównaniu do innych, pozwalając na zwolnienie tych ostatnich ze zobowiązań dotyczących redukcji wsparcia. Być może jest to wyjaśnienie sytuacji, w jaki sposób państwa - wypełniając zobowiązania Rundy Urugwajskiej - mogą nadal wspierać rolnictwo na poziomie sprzed Rundy.

\section{Wsparcie na rynku wewnętrznym}

W zakresie krajowego wsparcia rynku wewnętrznego centralnym pojęciem jest wskaźnik AMS (Aggregated Measurement of Support - zagregowany wskaźnik wsparcia), zdefiniowany w art. 1(a) jako,, poziom wsparcia w okresie rocznym, wyrażony w kategoriach pieniężnych, udzielony produktowi rolnemu i świadczony na rzecz producentów podstawowych produktów rolnych albo też wsparcie nie związane z konkretnym produktem, świadczone na rzecz ogółu producentów”. Załącznik nr 3 do Porozumienia określa szczegółowe wytyczne, w jaki sposób kalkulować wartość wsparcia cenowego, płatności bezpośrednich niepodlegających wyłączeniu oraz innych subsydiów niewyłączonych ze zobowiązań redukcyjnych.

Zgodnie z zapisami tego załącznika, wskaźnik wsparcia (AMS) należy kalkulować indywidualnie w odniesieniu do każdego produktu, uzyskującego jakiekolwiek wsparcie niewyłączone ze zobowiązań redukcyjnych. Załącznik (w ust. 1) stanowi, że wsparcie, które nie jest świadczone w odniesieniu do poszczególnych produktów, zostanie skalkulowane w postaci jednej liczby i włączone do ogólnego, łącznego wskaźnika wsparcia. Stosownie do treści ust. 7 załącznika nr 3, wskaźnik wsparcia dla danego produktu należy liczyć możliwie najbliżej pierwszego szczebla zbytu, dlu rolnego, J. A McMahon, The WTO Agreement on Agriculture, Era - Forum 2001, nr 4, s. 111 i nast.; T. Cottier, Dispute Settlement in the World Trade Organization, Charakteristics and Struktural Implications for the European Union, Common Market Law Reviev 1998, nr 2 (35), s. 325 i nast.; C. Ritson, D. Harvey, The Common Agricultural..., op. cit. 
natomiast środki przyznane na rzecz przetwórców artykułów rolnych uwzględniać należy jedynie $\mathrm{w}$ takim zakresie, $\mathrm{w}$ jakim korzystają $\mathrm{z}$ nich producenci podstawowych produktów rolnych.

Po skalkulowaniu wskaźnika wsparcia dla poszczególnych produktów wylicza się łączny zagregowany wskaźnik wsparcia (łączny AMS), który określony jest (w art. 1(h)) jako suma całego wsparcia krajowego, świadczonego na rzecz producentów rolnych - liczonego jako suma wszystkich zagregowanych wskaźników wsparcia dla podstawowych produktów rolnych, wszystkich zagregowanych wskaźników wsparcia niezwiązanych z określonymi produktami oraz wszystkich ekwiwalentnych wskaźników wsparcia produktów rolnych. Zgodnie z Modalities Agreement (Porozumienie w sprawie zasad szczegółowych), każdy rozwinięty kraj członkowski zredukować był winien łączny wskaźnik wsparcia o $20 \%$ podczas sześcioletniego okresu, kraje rozwijające się zobowiązane były do redukcji o 13,3\% w okresie dziesięcioletnim, natomiast w przypadku państw najmniej rozwiniętych odstąpiono od obowiązku redukcji.

W pierwszym sporze dotyczącym krajowego wsparcia Stany Zjednoczone i Australia oskarżyły Korę o przekroczenia poziomu zobowiązań w zakresie bieżącego, łącznego wskaźnika wsparcia na rok 1977, przy czym USA wniosły podobną skargę również w odniesieniu do 1998 r. ${ }^{7}$ Skarżący twierdzili, że właściwie skalkulowany wskaźnik wsparcia, jakiego Korea udzieliła krajowym producentom wołowiny przekraczał o $10 \%$ poziom de minimis, w związku z czym winien zostać włączony do kalkulacji koreańskiego bieżącego, łącznego AMS. Po przeprowadzeniu niezwykle skomplikowanej i żmudnej analizy postanowień Porozumienia, załącznika nr 3, Modalities Agreement, list koncesyjnych i innych, Panel generalnie przyznał rację skarżącym. Jednakże Organ Odwoławczy (do którego odwołała się Korea), pomimo że zgodził się z argumentacją Panelu we wszystkich kwestiach dotyczących krajowego wsparcia, to jednak unieważnił jego werdykt w sprawie przekroczenia przez Koreę poziomu wsparcia za wskazane powyżej lata.

Kolejna, głośna sprawa wniesiona przez Brazylię w 2002 r. (i wygrana), dotyczyła przyznawania przez Stany Zjednoczone subsydiów na rzecz producentów, użytkowników i eksporterów bawełny zwyczajnej ${ }^{8}$. Pomimo że Panel, a następnie Organ Odwoławczy zajęły się przede wszystkim sprawą subsydiów eksportowych, werdykty tych organów analizują postanowienia Porozumienia w sprawie rolnictwa dotyczące wsparcia krajowego. Niezmiernie złożona i rozległa materia prawna, analizowana przez te organy, przekracza ramy niniejszego opracowania.

Dla ilustracji wsparcia na rynku wewnętrznym można posłużyć się przykładem wspólnej organizacji rynku zboża, która w latach dziewięćdziesiątych prze- 
szła fundamentalne zmiany. Jądrem pierwotnej wersji wspólnej organizacji rynku zboża była cena docelowa (target price) i cena interwencyjna (intervention price). Cena docelowa (target price) wskazywała na poziom cenowy, którzy producenci we Wspólnocie mieli nadzieję osiągnąć, a którą na mocy prawa ustalano jako cenę uzyskiwaną w Duisburgu w Niemczech, leżącym w centrum regionu o największym deficycie zboża we Wspólnocie (chociaż te same ceny nominalne stosuje się na całym terenie Wspólnoty). Cena interwencyjna oznaczała tradycyjnie cenę, po której organy krajowe były zobowiązane do nabywania produktów objętych wsparciem cenowym, które zostały im zaoferowane, a którą ustalano jako cenę uzyskiwaną w Ormes we Francji, tj. w regionie o największej nadwyżce zbóż we Wspólnocie. Znaczenie geograficznej lokalizacji obu rodzajów cen polegało na tym, że różnica pomiędzy tymi cenami zawierała także element na pokrycie kosztów transportu pomiędzy Ormes a Duisburgiem ${ }^{9}$. W ramach reformy z 1992 roku cena docelowa i interwencyjna utraciły powiązanie geograficzne i zostały określone rozporządzeniem Rady $1766 / 92^{10}$, które ustanowiło je na poziomie niższym niż wcześniej i przewidywało redukcję tych cen o określone kwoty w okresie trzech lat. Cena docelowa po wejściu w życie Porozumienia Rundy Urugwajskiej w sprawie rolnictwa została zniesiona w roku 1995 rozporządzeniem Rady 1528/95 ${ }^{11}$. Rozporządzenie Rady 1253/1999 12 stanowiło o dalszej redukcji ceny interwencyjnej w latach gospodarczych 2000-2001 i 2001-2002, antycypując ostateczną redukcję tej ceny w roku gospodarczym 2002-2003. Natomiast rozporządzenie Rady 1251/1999 ${ }^{13}$ zwiększyło dopłaty bezpośrednie do niektórych upraw rolnych w latach gospodarczych 2000-2001 i 2001-2002, antycypując dalsze podwyżki w związku z ostateczną redukcją ceny interwencyjnej.

Tak stosowany mechanizm cenowy nie był wyłącznie domeną Wspólnoty Europejskiej. Można w tym miejscu przywołać amerykańską „,parity price”, opierającą się na koncepcji, zgodnie z którą należy zachować taki sam stosunek pomiędzy cenami płaconymi przez rolnika a cenami, które rolnik otrzymuje, bazując na sytuacji istniejącej w latach 1909-1914, czyli w latach uważanych za lata „normalne"14. Używano zatem kosztów do skalkulowania ceny, stosując algorytm opierający się na sytuacji w tamtych bazowych latach. Ponadto Amerykanie stosowali tzw. pożyczki ,non-recourse”. W ramach tego programu udostępniano rolnikom rządowe pożyczki, biorąc na zabezpieczenie kwalifikujące się zbiory. Jeśli ceny spadły poniżej poziomu przewidzianego w umowie pożyczkowej, w związku z czym rolnik nie

Zob. E. Tomkiewicz w monografii, A. Jurcewicz, B. Kozłowska, E. Tomkiewicz, Polityka rolna Wspólnoty Europejskiej w świetle ustawodawstwa i orzecznictwa, Warszawa 1995, s. 147-148.

Dz.Urz. WE 1992 L 181/21.

Dz.Urz. WE 1995 L 148/3.

Dz.Urz. WE 1999 L 160/18.

Dz.Urz. WE 1999 L 160/1.

Zob. K. Meyer, D. Pedersen, N. Thorson, J. Davidson, Agricultural Law, Cases and Materials, St. Paul 1984, s. 26-35. 
mógł spłacić pożyczki, to rząd przejmował zbiory, ale nie ubiegał się o odzyskanie kwoty pozostałej do spłacenia ze względu na charakter „non-recourse” takiej pożyczki. W przeciwnej sytuacji, jeśli rynkowe ceny przekroczyły ceny przewidziane umową pożyczkową, rolnik spłacał pożyczkę i zatrzymywał zysk. W praktyce działało to bardzo podobnie do wspólnotowego systemu interwencyjnego ${ }^{15}$.

Pomijając samą kwestię wsparcia jako takiego, należy zauważyć, że systemy wsparcia $\mathrm{z}$ subwencjami dla producentów powodują dwa poważne problemy handlowe. Z punktu widzenia zewnętrznych dostawców sprzedających do Wspólnoty taki system subwencji oznacza, że wewnętrzni producenci mogą sprzedawać po cenie światowej niższej od ich kosztów, jeżeli dotacja pokrywa różnicę, a zatem zewnętrzni dostawcy nie mają przewagi cenowej. Kwestia ta była przedmiotem sporu pomiędzy Stanami Zjednoczonymi a Wspólnotą w sprawie Oilseeds (oleistych). W ramach GATT Wspólnota udzieliła Stanom koncesji celnych na oleiste, ale chociaż dla oleistych istniała struktura cen docelowych i interwencyjnych ustanowiona rozporządzeniem Rady 136/66 ${ }^{16}$ - główny sposób, w jaki Wspólnota zapewniała, że za oleiste będą płacone wspólnotowe ceny był taki, że gdy tylko cena docelowa przewyższała cenę światową, Wspólnota wypłacała subwencję za oleiste wyprodukowane i przetworzone we Wspólnocie, pokrywającą różnicę pomiędzy ceną docelową a ceną na rynku światowym. Panel GATT ${ }^{17}$ orzekł, że wspólnotowy program subwencjonowania oleistych stanowi naruszenie koncesji celnych przyznanych Stanom Zjednoczonym, stwierdzając, że „Stany Zjednoczone nie mogły racjonalnie przewidzieć wprowadzenia programów subwencjonowania, które całkowicie chronią producentów przed ruchami cen w imporcie, a zatem uniemożliwiają koncesjom celnym wywieranie jakiegokolwiek wpływu na konkurencyjność oleistych z importu wobec oleistych z rynku wewnętrznego".

Innym, zapewne lepiej rozpoznanym, problemem wynikającym $\mathrm{z}$ subwencjonowania producentów jest subwencjonowany eksport - nawet gdy nie przyznaje się subwencji eksportowych jako takich. Najlepszych przykładów dostarcza sytuacja na rynkach Wspólnoty nieobjętych wspólną organizacją rynku. Na mocy artykułu 36 Traktatu, reguły konkurencji stosują się do rolnictwa tylko w zakresie określonym przez Radę w ramach wspólnej polityki rolnej, a w kontekście zasad udzielania pomocy krajowej (traktowanych przez Traktat jako reguły konkurencji) wykonywanie rozporządzenia Rady 26/62 nie powoduje stosowania zasad Traktatu do produktów rolnych. Artykuł 4 tego rozporządzenia stanowi jedynie o stosowaniu przepisów nakładających obowiązek weryfikacji istniejących systemów pomocy przez Komisję i obowiązek jej powiadamiania (notyfikacji) o nowych formach pomocy.

Zob. J.A. Usher, EC Agricultural..., op. cit., s. 62.

Dz.Urz. WE 1966, s. 3025.

Zob. P. Pescatore, W. Davey, A. Lowenfeld, Handbook of GATT Dispute Settlement, Irvington-on-Hudson, New York 1991, s. 525. 
Zatem stosowanie zasad udzielania pomocy krajowej do obrotu produktami rolnymi zależy od warunków określonych przepisami ustanawiającymi wspólną organizację rynku danych produktów ${ }^{18}$. Jednak tam, gdzie nie ma takiej wspólnej organizacji, nie ma także ogólnie obowiązujących zasad udzielania pomocy krajowej wobec producentów rolnych, co jasno stwierdził Trybunał Sprawiedliwości w odniesieniu do rynku ziemniaków w sprawie 114/83 Societé d'Initiatives v. Commission ${ }^{19}$. Mogą zatem wystąpić poważne trudności, jako że swobodny przepływ towarów stosuje się do produktów rolnych nieobjętych wspólną organizacją rynku, ale zasady stosowania pomocy krajowej nie stosują się do nich. Problem ten stanowił podłoże słynnego (a może raczej niesławnego) sporu o baraninę pomiędzy Wielką Brytanią a Francją, w którym Francja utrzymywała, że brytyjski system dopłat uzupełniających (deficiency payments) stanowił pomoc krajową. Jednakże Trybunał orzekł, że Francja nie może blokować ani ograniczać importu brytyjskiej baraniny objętej tymi dotacjami ${ }^{20}$, powodując totalne zagrożenie francuskiego systemu interwencyjnego wsparcia na rzecz krajowych producentów baraniny importem taniej baraniny z Wielkiej Brytanii. Rozwiązanie sugerowane przez Trybunał było takie, że nic nie stoi na przeszkodzie, aby francuskie władze wprowadziły własny system pomocy dla tego sektora do czasu ustanowienia wspólnej organizacji rynku baraniny.

Wracając do pomocy jako takiej, zasada określona artykułem III GATT brzmi: „strony uznają, że wewnętrzne podatki i inne wewnętrzne opłaty oraz regulacje prawne i wymagania wpływające na wewnętrzną sprzedaż, ofertę sprzedaży, zakup, transport, dystrybucję i używanie produktów, jak również wewnętrzne standardy ilościowe dotyczące mieszania, przetwarzania i używania produktów w określonej ilości lub proporcjach nie mogą być stosowane w odniesieniu do produktów wewnętrznych lub importowanych celem stworzenia ochrony wewnętrznej produkcji”. Tym niemniej artykuł III:8(b) stanowi, że ,zapisy niniejszego artykułu nie mogą uniemożliwiać wypłaty subwencji wyłącznie producentom wewnętrznym, w tym płatności na rzecz producentów wewnętrznych pochodzącej z wewnętrznych przychodów podatkowych lub opłat stosowanych w zgodności z niniejszym artykułem, jak również subwencji wykonywanych poprzez administracyjny skup produktów wewnętrznych". Mówi się zatem jasno, że można wypłacać dopłaty bezpośrednie producentom wewnętrznym nie oferując ich innym producentom oraz że produktom wewnętrznym można oferować subwencje poprzez administracyjny skup tych produktów (tj. ,skup interwencyjny” w potocznym języku Wspólnoty).

Aby jednak móc skorzystać z tego zwolnienia, subwencje dla producentów muszą być wypłacane bezpośrednio producentom, jak wskazano w sporze Wspólno- 
ty ze Stanami Zjednoczonymi w sprawie Oilseed ${ }^{21}$, w którym - jak już wspomniano - panel GATT uznał, że wspólnotowe programy subwencjonowania uniemożliwiają Stanom Zjednoczonym pełne korzystanie z koncesji celnych powodując, że koncesje te nie mają żadnego wpływu na konkurencyjność oleistych z importu wobec oleistych z rynku wewnętrznego. Panel zająl jednak inne stanowisko w kwestii legalności subwencji niż Trybunał Sprawiedliwości. W sprawach 67-85/75 Lesieur Cotelle and Others v. Commission ${ }^{22}$ Trybunał orzekł, że subwencja za oleiste zebrane i przetworzone we Wspólnocie - zgodnie z rozporządzeniem Rady 136/66 $6^{23}$ - została zamierzona jako gwarancja dla plantatorów oleistych. Wnioski o subwencje składały jednak rafinerie, a nie plantatorzy. Trybunał orzekł, że jeżeli zamiarem rozporządzenia 136/66 było udzielenie gwarancji, to gwarancje te powinny zostać udzielone plantatorom rzepaku, a nie rafineriom, co można wnosić z artykułu 24 tego rozporządzenia, zgodnie z którym wynikająca zeń cena interwencyjna gwarantowała, że producenci będą mogli sprzedać produkt po cenie, która - umożliwiając fluktuację rynku - będzie jak najbliższa cenie docelowej. Nie było natomiast zamiarem ustawodawcy wypłacanie subwencji przetwórcom oleistych jako gwarancji stałej opłaty za wykonywane przez nich przetwórstwo, ale umożliwienie im nabywania wspólnotowych oleistych za ceny bliskie cenie docelowej. Trybunał orzekł, że przetwórcy nie mają prawa żądać żadnej gwarancji na mocy rozporządzenia Rady 136/66. Natomiast panel GATT zajął stanowisko, że płatność, która nie została dokonana bezpośrednio na rzecz producentów nie jest wypłacona „wyłącznie” producentom w rozumieniu artykułu III:8(b) oraz uznał, że wspólnotowe rozporządzenie wcale nie zagwarantowało, że płatności dla producentów będą opierać się na cenach, które przetwórcy będą zmuszeni zapłacić kupując wspólnotowe oleiste.

Zgodnie z artykułem 3 Porozumienia Rundy Urugwajskiej w sprawie rolnictwa „Członek Porozumienia nie może wspierać wewnętrznych producentów powyżej poziomu, do którego się zobowiązał, określonego w sekcji 1, części IV niniejszego Harmonogramu" i chociaż w przypadku Wspólnoty wewnętrzne wsparcie winno zostać zredukowane o 20\% ogółem (ale w odniesieniu do lat 1986-1988), to jednak na mocy artykułu 6(5) i aneksu II nie ma obowiązku redukowania płatności wypłacanych w ramach programów zmniejszania produkcji (np. set-aside, czyli wyłączania gruntów z produkcji rolnej ${ }^{24}$ ) ani płatności decoupled income support (oddzielone od produkcji wsparcie dochodów). Artykuł 6 Porozumienia stanowi, że zobowiązania w kwestii redukcji wewnętrznego wsparcia każdego członka Porozumienia określone częścią IV Harmonogramu ,winny stosować się do wszystkich wewnętrz-

Zob. P. Pescatore, W. Davey, A. Lowenfeld, Handbook of GATT..., op. cit., s. 525.

ECR 1976, s. 391.

Dz.Urz. WE 1966, s. 3025.

Zob. A. Jurcewicz, Prawne formy i skutki wyłączania gruntów z produkcji rolnej w świetle ustawodawstwa EWG, „Prawo Rolne” 1991, nr 2, s. 5-23; A. Lichorowicz, Problematyka struktur agrarnych w ustawodawstwie Wspólnoty Europejskiej, Zakamycze, Kraków 1996, s. 156 i nast.; E. Tomkiewicz, Limitowanie produkcji w ustawodawstwie rolnym Wspólnoty Europejskiej, Warszawa 2000, s. 95-105. 
nych instrumentów wsparcia na rzecz producentów rolnych, poza tymi wewnętrznymi środkami, które nie podlegają redukcji na warunkach określonych niniejszym artykułem i aneksem 2 do niniejszego Porozumienia" ${ }^{25}$.

Z drugiej strony, na mocy artykułu 6(5) płatności bezpośrednie w ramach programów zmniejszania produkcji nie podlegają zobowiązaniom w kwestii redukcji wewnętrznego wsparcia, jeżeli płatności mają za podstawę stałą powierzchnię i plony, bądź wypłacane są za $85 \%$ lub mniej bazowego poziomu produkcji, a w przypadku żywca - wypłacane są na podstawie stałego pogłowia (blue box „,niebieska skrzynka”). W tym kontekście można zauważyć, że na przykład dopłaty powierzchniowe na mocy artykułu 4 rozporządzenia Rady 1251/199926 w sprawie systemu wsparcia dla producentów niektórych upraw rolnych, które kalkuluje się mnożąc podstawową kwotę dopłaty do jednej tony przez średni plon określony $\mathrm{w}$ planie regionalizacji dla danego regionu, podlegają zobowiązaniom w kwestii set aside (obecnie zgodnie $\mathrm{z}$ artykułem 6 rozporządzenia jest to 10\%, ale na moment zakończenia negocjacji Rundy Urugwajskiej było to $15 \%$ na mocy artykułu 7 rozporządzenia Rady $1765 / 92^{27}$ ). Dopłaty powierzchniowe przewidziano także dla sektora wołowiny - na mocy rozporządzenia Rady 1765/92 ${ }^{28}$, a od roku 2005 w sektorze mleczarskim - na mocy rozporządzenia $1255 / 99^{29}$. W odniesieniu do żywca dokonuje się płatności na stałe pogłowie zwierząt - najlepszym przykładem są tu premie za maciorki (ewe headage payment) wypłacane na mocy rozporządzenia Rady 2647/98 w sprawie wspólnej organizacji rynku baraniny ${ }^{30}$ : określono w nim maksymalne pogłowie premiowanych maciorek na $63.400 .000 \mathrm{sztuk}^{31}$.

Artykuł 6(5)(b) Porozumienia wyraźnie mówi, że zwolnienie płatności bezpośrednich spełniających powyższe kryteria ze zobowiązań w kwestii redukcji winno

Formy wewnętrznego wsparcia podlegające Porozumieniu w sprawie rolnictwa określa się obrazowo za pomoca skrzynek o trzech kolorach, ciemnożółtym (amber box), niebieskim (blue box) i zielonym (green box). Amber box oznacza wszelkie środki wsparcia wewnętrznego, które uważa się za zakłócające konkurencję i handel (z pewnymi wyjątkami), zdefiniowane w art. 6 porozumienia jako wsparcie wewnętrzne inne niż należące do blue box lub green box. Zalicza się do nich wsparcie cen rynkowych i płatności bezpośrednie na rzecz producentów. Dozwolone jest wsparcie minimalne, w wysokości nieprzekraczającej $5 \%$ produkcji dla państw rozwiniętych i 10\% dla rozwijających się. Blue box oznacza wsparcie wewnętrzne, które nie kwalifikuje się do amber box tylko dlatego, że wiąże się z ograniczeniem produkcji rolnej, innymi słowy przypisane jest do obszaru (wielkości) gospodarstwa, a nie wielkości produkcji (art. 6 ust. 5 Porozumienia). Green box oznacza środki, które w niewielkim stopniu zakłócają handel, nawet jeśli dotyczą bezpośrednio produkcji. W załączniku 2 Porozumienia zdefiniowano je jako wsparcie udzielane w ramach programów rządowych finansowanych ze środków publicznych (łącznie z zaniechanymi należnościami finansów publicznych), nieobejmujące transferów od konsumentów oraz wsparcie, które nie spowoduje podtrzymywania cen producentów (do grupy tej należą np. środki na zwalczanie epidemii, promocję i marketing, rządowe finansowanie zapasów żywności ze względów bezpieczeństwa, środki pomocowe na dostosowania o charakterze strukturalnym i na cele rozwoju regionalnego, rządowe wsparcie wydatków na badania i rozwój).

Dz.Urz. WE 1992 L 181/12.

Dz.Urz. WE 1999 L 160/21, Aneks IV.

Dz.Urz. WE 1999 L 160/48.

Dz.Urz. WE 1998 L 312/1.

Zob. art. 13(1). 
odzwierciedlać się w wyłączeniu wartości tych płatności z kalkulacji wewnętrznego wsparcia ogółem u danego członka Porozumienia.

Aneks 2 określa bardziej szczegółowo instrumenty wewnętrznego wsparcia, które nie podlegają zobowiązaniom w kwestii redukcji. Ogólna zasada ustanowiona w ustępie pierwszym stanowi, że polityka wewnętrznego wsparcia ubiegająca się o zwolnienie ze zobowiązań w kwestii redukcji „winna spełniać fundamentalny wymóg, że nie powoduje lub powoduje w jak najmniejszym stopniu, efekt znieksztalcenia handlu lub produkcji”(green box - „zielona skrzynka”). Określono, że każda polityka wewnętrznego wsparcia ubiegająca się o zwolnienie ze zobowiązań w kwestii redukcji winna spełniać następujące podstawowe kryteria:

- wsparcia należy udzielać poprzez finansowany ze środków publicznych program rządowy (w tym również z przyszłych przychodów administracji publicznej - government revenue forgone) niepociągający za sobą transferu środków od konsumentów oraz

- wsparcie nie może powodować efektu wsparcia cenowego dla producentów.

Jeżeli chodzi o płatności bezpośrednie dla producentów, ustęp 5 stanowi, że wsparcie poprzez płatności bezpośrednie dla producentów (lub przyszłe przychody, w tym płatności w naturze), które ubiega się o zwolnienie ze zobowiązań w kwestii redukcji, winno spełniać podstawowe kryteria określone ustępem 1 (przytoczone powyżej) oraz dodatkowe kryteria stosujące się do poszczególnych rodzajów płatności bezpośrednich, określone w ustępach od 6 do 13. Przy ubieganiu się o zwolnienie ze zobowiązań w kwestii redukcji dla jakiejkolwiek istniejącej lub nowej płatności bezpośredniej innej niż płatności określone ustępami od 6 do 13, poza spełnieniem kryteriów ogólnych określonych ustępem 1, należy spełnić kryteria od (a) do (e) ustępu 6.

Ustęp 6 dotyczy „,decoupled income support” (wsparcie dochodów oddzielone od produkcji), tj. płatności, które - chociaż mogą być wyliczone na podstawie produkcji w roku bazowym - nie zależą od produkcji bieżącej. Stanowi on, że:

(a) Kwalifikowanie się do takich płatności należy określać na podstawie jasno zdefiniowanych kryteriów, takich jak dochody, status producenta lub właściciela gruntów, środki produkcji lub poziom produkcji w zdefiniowanym i określonym na stałe okresie bazowym.

(b) Kwota takich płatności w jakimkolwiek roku nie może mieć związku ani opierać się na rodzaju i wolumenie produkcji (w tym na sztukach pogłowia) prowadzonej w jakimkolwiek roku po okresie bazowym.

(c) Kwota takich płatności w jakimkolwiek roku nie może mieć związku ani oparcia w cenach - krajowych i międzynarodowych - stosowanych w od- 
niesieniu do produkcji prowadzonej w jakimkolwiek roku po okresie bazowym.

(d) Kwota takich płatności w jakimkolwiek roku nie może mieć związku ani oparcia w środkach produkcji stosowanych w jakimkolwiek roku po okresie bazowym.

(e) Nie wolno wymagać prowadzenia jakiejkolwiek produkcji celem otrzymania takich płatności.

Można utrzymywać, że omawiane powyżej wspólnotowe płatności spełniają te kryteria.

Ustęp 7 zajmuje się finansowym udziałem państwa w programach ubezpieczania i zabezpieczania dochodów (income insurance and income safety-net programmes) pod warunkiem, że spełniają one następujące kryteria:

(a) Kwalifikowanie się do takich płatności określa się na podstawie utraconych dochodów, biorąc pod uwagę jedynie dochody z rolnictwa - producent kwalifikuje się, gdy utrata dochodów przekracza 30\% przeciętnych dochodów brutto lub równowartość w dochodach netto (z wyłączeniem płatności $\mathrm{z}$ tego programu lub programów o podobnym charakterze) w poprzednich trzech latach lub średnią $\mathrm{z}$ trzech lat w poprzednich pięciu latach, poza rokiem o najwyższych dochodach i rokiem o najniższych dochodach. Każdy producent spełniający te warunki kwalifikuje się do otrzymania płatności.

(b) Kwota tych płatności może zrekompensować mniej niż 70\% utraconych dochodów danego producenta w roku, w którym producent zakwalifikował się do otrzymywania tej dotacji.

(c) Kwota takich płatności winna odnosić się jedynie do dochodów; nie może odnosić się do rodzaju lub wolumenu produkcji (w tym do sztuk pogłowia) prowadzonej przez producenta, ani do cen - krajowych i międzynarodowych - stosujących się do tej produkcji, ani do wykorzystywanych środków produkcji.

(d) Jeżeli w tym samym roku producent otrzymuje płatności na mocy tego ustępu oraz na mocy ustępu 8 (pomoc przy klęskach żywiołowych), kwota tych płatności ogółem winna wynosić poniżej $100 \%$ utraty dochodów danego producenta.

Płatności na mocy ustępu 8 (wypłacane bezpośrednio lub poprzez rządowe dofinansowanie ubezpieczeń zbiorów) przyznawane jako pomoc przy klęskach żywiołowych nie są wliczane do kalkulacji wewnętrznego wsparcia (domestic support), pod warunkiem, że kwalifikowanie się do takich płatności następuje wyłącznie po formalnym stwierdzeniu przez kompetentne władze zaistnienia klęski żywiołowej lub innych wydarzeń o podobnym charakterze (w tym wybuchu epidemii, plagi 
szkodników, wypadków atomowych lub wojny na terenie państwa członkowskiego Porozumienia) i określane są na podstawie utraconej produkcji, gdy utrata produkcji przekracza $30 \%$ przeciętnej produkcji w poprzednich trzech latach lub średnią z trzech lat w poprzednich pięciu latach, poza rokiem o najwyższej produkcji i rokiem o najniższej produkcji. Zatem rekompensaty wypłacone za wybijanie stad podczas epidemii pryszczycy nie zostały wliczone do kwoty wewnętrznego wsparcia. Ponadto, mówi się jasno, że pomoc przy klęskach żywiołowych ma zastosowanie wyłącznie w odniesieniu do strat dochodów, strat w żywym inwentarzu (w tym płatności związane z weterynaryjnym leczeniem zwierząt), strat dotyczących gruntów i innych środków produkcji, które zostały spowodowane daną klęską żywiołową, a płatności z tego tytułu nie mogą przekroczyć kosztów naprawy szkód, nie mogą także określać ani wymagać rodzaju czy wolumenu przyszłej produkcji, ani przekroczyć poziomu niezbędnego do zapobieżenia kolejnym stratom lub ich złagodzenia. Jeżeli w tym samym roku producent otrzymuje płatności na mocy tego ustępu oraz na mocy ustępu 7 (income insurance and safety-net programmes), kwota tych płatności ogółem winna wynosić poniżej $100 \%$ strat poniesionych przez danego producenta.

Na mocy ustępu 9 wyłączeniu podlega natomiast wsparcie na dostosowania strukturalne (structural adjustment assistance) udzielane poprzez programy emerytalne dla producentów, takie jak określone artykułami 10-12 rozporządzenia Rady $1257 / 1999$ w sprawie wsparcia rozwoju obszarów wiejskich z FEOGA ${ }^{32}$. Ustęp ten stanowi, że kwalifikowanie się do takich płatności należy określać na podstawie jasno zdefiniowanych kryteriów w ramach programów mających ułatwić przejście na emeryturę osobom prowadzącym towarową działalność rolniczą lub ich przestawienie na działalność pozarolniczą, a także, że płatności te uwarunkowane są całkowitym zarzuceniem towarowej działalności rolniczej na stałe.

Na mocy ustępu 10 z kwoty wsparcia wewnętrznego ogółem wyłączona został ,pomoc na dostosowania strukturalne poprzez programy wycofywania zasobów" (resource retirement programmes), tj. środki takie jak set-aside, grubbingup i program outgoers. Kwalifikowanie się do takich płatności należy określać na podstawie jasno zdefiniowanych kryteriów w ramach programów służących do wycofywania gruntów lub innych środków produkcji, w tym żywego inwentarza, z towarowej działalności rolniczej, a płatności muszą być uwarunkowane wycofaniem gruntów z towarowej działalności rolniczej na co najmniej trzy lata, a w przypadku żywca - ubojem lub ostatecznym wyzbyciem się zwierząt na stałe. Płatności nie mogą określać ani wymagać żadnego alternatywnego wykorzystania takich gruntów lub innych zasobów, które wiązałoby się z wytwarzaniem produktów rolnych przeznaczonych na rynek, jak również nie mogą być powiązane z rodzajem i wolume- 
nem produkcji, ani z cenami - krajowymi i międzynarodowymi - stosującymi się do produkcji prowadzonej przy wykorzystaniu pozostających w produkcji gruntów i innych zasobów.

Pomoc na dostosowania strukturalne udzielana jako pomoc inwestycyjna została wyłączona z kwoty wsparcia ogółem na mocy ustępu 11. Kwalifikowanie się do takich płatności należy określać na podstawie jasno zdefiniowanych kryteriów w ramach programów rządowych, mających służyć pomocą w finansowej lub fizycznej restrukturyzacji działalności prowadzonej przez producenta - jako odpowiedź na obiektywnie wykazane upośledzenie (defaworyzację) strukturalne, jak np. wparcie dla terenów o trudnych warunkach gospodarowania (support for less-favoured areas) na mocy rozdziału V rozporządzenia Rady 1257/1999 w sprawie wsparcia rozwoju obszarów wiejskich z FEOGA ${ }^{33}$. Kwalifikowanie się do takich programów może również opierać się na jasno zdefiniowanych rządowych programach reprywatyzacji gruntów rolnych, co jest kwestią o pewnym znaczeniu dla państw Europy Środkowej i Wschodniej. Kwota takich płatności w jakimkolwiek roku nie może mieć związku ani opierać się na rodzaju i wolumenie produkcji (w tym na sztukach pogłowia) prowadzonej w jakimkolwiek roku po okresie bazowym, ani nie może mieć związku, ani oparcia w cenach - krajowych i międzynarodowych - stosowanych w odniesieniu do produkcji prowadzonej w jakimkolwiek roku po okresie bazowym. Płatności wypłacane są jedynie przez okres czasu niezbędny do realizacji inwestycji, na którą je przyznano i nie mogą postulować ani określać produktów rolnych, które mają wytwarzać beneficjenci, poza tym, że mogą wymagać, aby producenci nie produkowali jakiegoś konkretnego produktu. Wreszcie płatności te winny zostać ograniczone do kwoty, która rekompensuje strukturalne upośledzenie (defaworyzację).

Płatności w ramach programów środowiskowych są także wyłączone z kwoty wsparcia ogółem, co - jak się wydaje - obejmuje wsparcie prośrodowiskowych metod produkcji rolnej i prośrodowiskowych zobowiązań na mocy artykułów 22-24 rozporządzenia Rady 1257/1999 w sprawie wsparcia rozwoju obszarów wiejskich z FEOGA ${ }^{34}$. Ustęp 12 wymaga, aby kwalifikowanie się do takich płatności następowało na podstawie jasno zdefiniowanych rządowych programów środowiskowych (environmental and conservation programmes) i zależało od spełnienia warunków danego programu, w tym warunków dotyczących metody lub środków produkcji, ale kwotę takich płatności należy ograniczyć do wartości dodatkowych kosztów lub straty dochodów spowodowanych stosowaniem się do danego programu rządowego. 
$\mathrm{Z}$ wyliczenia kwoty wsparcia ogółem wyłączone są także programy regionalne (regional assistance programmes). Na mocy ustępu 13 kwalifikowanie się do takich płatności ogranicza się do producentów w regionach upośledzonych, a każdy taki region winien stanowić jasno określony spójny obszar geograficzny o definiowalnej tożsamości gospodarczej i administracyjnej, uważany za upośledzony na podstawie neutralnych i obiektywnych kryteriów, jasno ustanowionych przepisami i wskazujących, że trudności w tym regionie nie mają charakteru przejściowego. W kontekście UE, na mocy rozporządzenia Rady 1258/1999 w sprawie finansowania wspólnej polityki rolnej ${ }^{35}$, Sekcja Orientacji finansuje w zasadzie jedynie środki rozwoju obszarów wiejskich objęte Celem 1 oraz wspólnotową inicjatywę rozwoju obszarów wiejskich. Rozporządzenie Rady 1260/199936 w sprawie funduszy strukturalnych określa Cel 1 jako tereny, gdzie produkt krajowy brutto per capita, rozumiany jako siła nabywcza, jest poniżej 75\% wspólnotowej średniej ${ }^{37}$, stanowiąc, że $69,7 \%$ z 195 miliardów EUR przyznanych na fundusze strukturalne na lata 2000-2006 powinno zostać przeznaczone na przedsięwzięcia w obrębie Celu $1^{38}$.

Następnie ustęp ten stanowi, że kwota takich płatności w jakimkolwiek roku nie może mieć związku ani opierać się na rodzaju i wolumenie produkcji (w tym na sztukach pogłowia) prowadzonej w jakimkolwiek roku po okresie bazowym, ani nie może mieć związku, ani oparcia w cenach - krajowych i międzynarodowych - stosowanych w odniesieniu do produkcji prowadzonej w jakimkolwiek roku po okresie bazowym. Płatności winny być dostępne jedynie dla producentów w kwalifikujących się regionach, ale muszą być ogólnie dostępne dla wszystkich producentów tych regionów. Jeżeli płatności mają związek ze środkami produkcji (production factors), stawka płatności powinna zmniejszać się powyżej pewnego progu określonego dla danego środka produkcji. Wreszcie kwotę takich płatności należy ograniczyć do wartości dodatkowych kosztów lub straty dochodów spowodowanych gospodarowaniem $\mathrm{w}$ regionie upośledzonym.

Patrząc z perspektywy UE, Porozumienie w sprawie rolnictwa zachęciło do przechodzenia - rozpoczętego wcześniej - od systemu wsparcia produktów (interwencji) do systemu zawierającego element wsparcia dla producentów (dopłaty powierzchniowe i set-aside). To przesunięcie spowodowało automatycznie redukcję kwoty wewnętrznego wsparcia ogółem wyliczaną dla potrzeb WTO oraz zredukowało poziom wsparcia eksportu. Jak wspomniano powyżej, rozporządzenie Rady $1253 / 1999^{39}$ stanowiło o dalszej redukcji ceny interwencyjnej w latach gospodarczych 2000-2001 i 2001-2002, antycypując ostateczną redukcję tej ceny w roku go- 
spodarczym 2002-2003. Natomiast rozporządzenie Rady 1251/199940 zwiększyło dopłaty bezpośrednie do niektórych upraw rolnych w latach gospodarczych 20002001 i 2001-2002, antycypując dalsze podwyżki w związku z ostateczną redukcją ceny interwencyjnej.

\section{Narzuty na import i dostęp do rynku}

W tradycyjnym wspólnotowym systemie wsparcia, zobrazowanym wcześniej na przykładzie wspólnej organizacji rynku zbóż, opierającym się na cenach docelowych z Duisburga i interwencyjnych z Ormes, położenie geograficzne odgrywało pewną rolę w odniesieniu do zewnętrznych aspektów struktury cen: chcąc zapewnić, aby struktura cen nie została zaburzona przez tani import, wprowadzono cenę progu (threshold price), określaną dla portu w Rotterdamie, stanowiącą minimalną cenę, po której towary z importu mogą wejść na terytorium Wspólnoty. Cenę tę kalkulowano nie w oparciu o cenę interwencyjną, ale w oparciu o wyższą cenę docelową (w ten sposób zmniejszano prawdopodobieństwo zejścia poniżej ceny interwencyjnej), a różnica pomiędzy ceną docelową i ceną progu zawierała ponownie element na pokrycie kosztów transportu pomiędzy Rotterdamem a Duisburgiem. Podobnie do cen docelowej i interwencyjnej - w ramach nowej wspólnej organizacji rynku z roku 1992 - cena progu straciła powiązanie geograficzne i została określona rozporządzeniem Rady 1766/92, stanowiącym o jej redukcji w okresie kolejnych trzech lat.

Jeżeli (co zwykle miało miejsce) cena światowa wyliczona na bazie CIF w Roterdamie była niższa od ceny progu, różnicę należało pokryć opłatą wyrównawczą (import levy). Status prawny opłat wyrównawczych stał się przedmiotem sporów. Mimo że prowadziły one do ochrony zewnętrznej, UE utrzymywała, że ze względu na ich cel, należy je odróżnić od ceł. W sprawie 17/67 Neumann v. Hauptzollamt Hof $^{41}$ Trybunał wskazał, że bez względu na podobieństwo opłat wyrównawczych do ceł, opłata była narzutem ( a charge) regulującym handel zewnętrzny związany ze wspólną polityką cenową, a nie cłem jako takim.

Mówiąc o tych restrykcjach importowych utrzymywano, że GATT nie zakazuje (variable levies) zmiennych opłat wyrównawczych z wyjątkiem sytuacji, gdy dany produkt korzysta $\mathrm{z}$ koncesji celnych ${ }^{42}$, chociaż inni wskazywali, że opłaty te to ilościowe restrykcje (quantitative restrictions) określone artykułem $\mathrm{XI}^{43}$. Nie negowano jednak legalności tych opłat, poza jednym przypadkiem, gdy Wspólnota wpro-

Dz.Urz. WE 1999 L 160/1

ECR 1967, s. 441.

Zob. I. Garcia Bercero, Trade Laws, GATT and the Management of Trade Disputes between the US and the EEC, Yearbook of International Law 1985, nr 149, s. 165.

43 Zob. E. McGovern, International Trade Regulation, GATT, the United States and the European Community, Exeter 1982, s. 342. 
wadzając wspólną organizację rynku, próbowała negocjować wycofanie koncesji udzielonych wcześniej przez państwa członkowskie w odniesieniu do produktów objętych tą organizacją. Miało to miejsce przy wprowadzaniu wspólnej organizacji rynku drobiu, stając się powodem do „chicken war” (wojny o kurczaki) ze Stanami Zjednoczonymi ${ }^{44}$, która nie doprowadziła jednak do sporu o te fundamentalne kwestie, ale do panelu zakończonego kompromisem w sprawie wartości restrykcji importowych, które mają stosować USA w odpowiedzi na wspólnotową zmienną opłatę wyrównawczą nakładaną na import drobiu.

W każdym razie, podczas gdy artykuł XI:1 GATT stanowi, że w zasadzie import i eksport nie powinny podlegać zakazom i restrykcjom innym niż cła, podatki $\mathrm{i}$ inne narzuty, realizowane poprzez kontyngenty oraz licencje importowe i eksportowe bądź inne środki, artykuł XI:2 zezwala na restrykcje importowe wobec produktów rolnictwa i rybołówstwa, importowanych w jakiejkolwiek formie, koniecznych dla wzmocnienia rządowych działań służących:

(a) ograniczeniu ilości podobnych produktów wewnętrznych, która może być wprowadzona na rynek lub wyprodukowana, bądź jeżeli nie ma znaczącej wewnętrznej produkcji podobnych produktów, produktów wewnętrznych mogących bezpośrednio zastąpić dane produkty z importu;

(b) wyzbyciu się tymczasowej nadwyżki podobnych produktów wewnętrznych, bądź jeżeli nie ma znaczącej wewnętrznej produkcji podobnych produktów, produktów wewnętrznych mogących bezpośrednio zastąpić dane produkty $\mathrm{z}$ importu, poprzez udostępnienie tej nadwyżki pewnym grupom wewnętrznych konsumentów nieodpłatnie lub po cenach poniżej aktualnej ceny rynkowej;

(c) ograniczeniu ilości produktów pochodzenia zwierzęcego, która może być wyprodukowana, a która bezpośrednio, w całości lub w większości, zależy od importowanego towaru, jeżeli wewnętrzna produkcja danego towaru jest nieznaczna.

Restrykcje te nie mogą jednak „,zmniejszać importu ogółem wobec wewnętrznej produkcji ogółem w porównaniu ze stosunkiem pomiędzy nimi, którego można by racjonalnie oczekiwać w przypadku braku restrykcji". Zatem restrykcje importowe mogą być usprawiedliwione, jeśli są powiązane $\mathrm{z}$ regulacją wewnętrznego ryn$\mathrm{ku}$ - a we Wspólnocie w wielu wspólnych organizacjach rynku rzeczywiście istnieją limity produkcyjne w różnych formach, takich jak kwoty i progi gwarancyjne (guarantee thresholds).

$\mathrm{Z}$ drugiej strony, wspólnotowe restrykcje importowe uznano za naruszenie artykułu XI. Stało się tak w przypadku koncentratu pomidorowego ${ }^{45}$, gdy Wspólnota 
wprowadziła minimalną cenę importową, poniżej której import był zakazany oraz obowiązkowy depozyt podlegający przepadkowi, jeśli import odbywał się poniżej tej ceny. Uznano, że przepadek był restrykcją w rozumieniu artykułu XI, a system wsparcia produkcji pomidora nie stanowił rządowego środka ograniczającego wewnętrzną produkcję w rozumieniu artykułu XI:2(c).

Fundamentalnym celem Porozumienia w odniesieniu do restrykcji importowych była konwersja istniejących legalnych restrykcji na cła, w imię lepszej przejrzystości, przy jednoczesnym zobowiązaniu się do ich redukcji. Na mocy artykułu 4(2) państwa członkowskie Porozumienia nie mogą utrzymywać ani wprowadzać żadnych środków, wobec których istnieje wymóg konwersji na zwykłe cła, o ile artykuł 5 nie stanowi inaczej (zezwala na powzięcie środków ochronnych (safeguard measures), jeśli wolumen importu przekracza pewien próg (trigger level) lub cena w imporcie spada poniżej pewnego progu (trigger level) lub jest to jeden ze specjalnych przypadków określonych aneksem 5. Przypis do artykułu 4(2) odgrywa ważną rolę definiując środki, które należy zamienić na zwykłe cła: „Środki te obejmują ilościowe restrykcje importowe, zmienne opłaty wyrównawcze, minimalne ceny importowe, dyskrecjonalne licencjonowanie importu, środki pozataryfowe stosowane przez państwowe przedsiębiorstwa handlowe, dobrowolne ograniczenia eksportowe i podobne środki graniczne inne niż zwykłe cła, bez względu na to, czy są stosowane na mocy derogacji dla danego państwa od zapisów GATT 1947, ale nie obejmuje środków stosowanych na mocy zapisów o bilansie płatniczym ani na mocy innych ogólnych zapisów GATT 1994 niedotyczących rolnictwa lub zapisów Multilateral Trade Agreements w aneksie 1A do WTO."

W kontekście UE oznaczało to, że opłaty wyrównawcze należy zamienić na cła, w przypadku UE zmniejszone średnio o $36 \%$ w stosunku do okresu bazowego 1986-1988. Zobowiązania UE do konwersji opłat wyrównawczych na cła i zmniejszenia wsparcia w ramach Porozumienia Rundy Urugwajskiej zostały wprowadzone w życie rozporządzeniem Rady 3290/9446, jednak na rynku zbóż stawki celne wydają się stałe (flat-rate). Wpływ starych opłat wyrównawczych nie zniknął całkowicie, co odzwierciedliło się $w$ fakcie, że gdy stare opłaty malały, rósł poziom cen światowych, a zatem cło dodawano do wysokiej z zasady ceny światowej: w normalnych warunkach to cło wyznaczało limit należnych opłat importowych, ale na mocy artykułu 10(2) rozporządzenia 1766/92, znowelizowanego rozporządzeniem 3290/94 w odniesieniu do wielu produktów, rzeczywista należność jest równa odnośnej cenie interwencyjnej powiększonej o 55\% minus cena importowa CIF, pod warunkiem, że nie przekracza cła CCT. Praktyczny skutek to redukcja opłat importowych do poziomu niższego od cła, jeśli światowa cena danych produktów rośnie. Tym niemniej, konsekwencją zmian ceł było to, że cena progu stała się niepotrzeb- 
na, a i cena docelowa nie służyła już żadnym praktycznym celom i została zniesiona rozporządzeniem Rady 1528/95 ${ }^{47}$.

Poza kwestiami objętymi Porozumieniem, wpływ podstawowych zasad GATT dotyczących klauzuli największego uprzywilejowania - z artykułu 1 - oraz zasady niedyskryminacji w odniesieniu do kontyngentów, a w szczególności kontyngentów celnych - z artykułu XII - na ewolucję wspólnej organizacji rynku widać bardzo dobrze na przykładzie sektora bananów. Wspólna organizacja rynku bananów została wprowadzona dopiero w roku 1993 rozporządzeniem Rady 404/93 ${ }^{48}$. Czas jej wprowadzenia był zapewne związany z realizacją jednolitego rynku wewnętrznego (single internal market) przed końcem 1992 roku na mocy artykułu 14 Traktatu WE, jako że Wielka Brytania i Francja posiadały system kontyngentów preferujący import bananów z ich dawnych kolonii i zostały wcześniej upoważnione, aby nie traktować jako ,wspólnotowych” bananów z innych krajów mogących swobodnie cyrkulować po terytoriach innych państw członkowskich. Na poziomie wewnętrznym wspólna organizacja rynku umożliwiała udzielanie skromnego wsparcia poprzez organizacje producentów, ale jedynie za stały poziom produkcji ${ }^{49}$ i wypłatę premii wspólnotowym producentom, którzy zarzucali produkcję bananów ${ }^{50}$. Jednak przeważająca część bananów konsumowanych w UE to banany importowane z krajów trzecich i konflikt z zasadami WTO dotyczył właśnie tego importu. Rozporządzenie przewidywało różne traktowanie tradycyjnego importu z państw $\mathrm{ACP}^{51}$ w wysokości 857700 ton, nietradycyjnego importu z państw ACP i importu z krajów trzecich nie-ACP. Tradycyjny import ACP był wolny od cła, ustanowiono kontyngent w wysokości 2 milionów ton, w ramach którego za import z krajów trzecich nie-ACP płacono cło 75 EUR za tonę, a nietradycyjny import z krajów ACP był wolny od cła. Kontyngent ten w roku 1995 podniesiono do 2,2 miliona ton, a następnie dodano doń kolejne 353 tysiące ton wskutek rozszerzenia UE z roku 1995. Poza tym kontyngentem import podlegał Wspólnej Taryfie Celnej, ale dla nietradycyjnego importu z krajów ACP stosowano zredukowaną stawkę 100 EUR za tonę.

Import podlegał licencjonowaniu ${ }^{52}$, a kontyngenty były początkowo rozdzielone w proporcji $66,5 \%$ dla podmiotów wprowadzających na rynek banany z krajów trzech i/lub banany z nietradycyjnego importu z krajów ACP, 30\% dla podmiotów wprowadzających na rynek banany ze Wspólnoty i/lub tradycyjny import bananów z krajów ACP i 3\% dla podmiotów z siedzibą we Wspólnocie, które zaczęły wprowadzać na rynek banany spoza Wspólnoty i/lub tradycyjny import z krajów ACP od 1992 roku. Przyznanie 30\% podmiotom wprowadzającym na rynek banany ze 
Wspólnoty i/lub banany z tradycyjnego importu z krajów ACP było jednym z czynników, które doprowadziły do tego, że organ apelacyjny $\mathrm{WTO}^{53}$ stwierdził naruszenie artykułu 11 General Agreement on Trade in Services, który wymaga, aby nie defaworyzowano dostawców usług z innych państw członkowskich tego porozumienia. Już zresztą sam system zróżnicowania importu trudno było pogodzić z klauzulą największego uprzywilejowania określoną w artykule 1 GATT $^{54}$ i zasadą administrowania kontyngentami bez dyskryminacji, której wymaga artykuł XIII; zresztą w czasie Rundy Urugwajskiej UE negocjowała zwolnienie, które otrzymała w roku 1996. Orzeczono jednak, że zwolnienie to było sformułowane w taki sposób, że odnosiło się jedynie do klauzuli największego uprzywilejowania, natomiast nie obejmowało artykułu XIII, a zatem UE naruszyła wymóg administrowania kontyngentami bez dyskryminacji.

Tym niemniej, w arbitrażu ${ }^{55}$, który miał przesądzić o tym, do jakiego poziomu Stany Zjednoczone mogą zawiesić udzielone koncesje w reakcji na wspólnotowe regulacje naruszające GATT i GATS ${ }^{56}$, arbitrzy zasugerowali ${ }^{57}$ globalny kontyngent celny - pozostający w zgodności z zasadami WTO - w wysokości 2553 miliona ton obłożony cłem 75 EUR za tonę z nieograniczonym dostępem dla bananów ACP ze stawką zerową; preferencja dla krajów ACP byłaby w takim przypadku objęta przez zwolnienie. UE nie od razu poszła w kierunku tych zaleceń, chcąc chronić nie tyle producentów we Wspólnocie, ile interesy producentów w krajach ACP, przez co ucierpiała na zawieszeniu koncesji na 191,4 miliona USD rocznie przez Stany Zjednoczone. Zmiany w importowym zakresie wspólnej organizacji rynku nastąpiły dopiero w roku 2001, dzięki czemu osiągnięto porozumienie ze Stanami Zjednoczonymi i innymi pokrzywdzonymi co do kształtu przyszłej długoterminowej polityki.

System przejściowy został wprowadzony rozporządzeniem Rady 216/200158, którego preambuła odnosi się bezpośrednio do zaleceń wydanych przez organ arbitrażowy. Jeżeli chodzi o kwestię usług, nowy artykuł 19 stanowi, że kontyngentami celnymi można zarządzać zgodnie $\mathrm{z}$,metodą opartą na uwzględnianiu tradycyjnych przepływów handlowych... i/lub innymi metodami”. Wydaje się, że w porozumieniu ze Stanami Zjednoczonymi zamierzano odnieść się do historycznych referencji importerów ${ }^{59}$, ale po późniejszych negocjacjach z Ekwadorem ustalono, że $83 \%$ kontyngentów miało być zarządzane na podstawie historycznych referencji, a 17\%

W istocie, art. 168(2)(a)(ii) Czwartej Konwencji z Lome wymaga od Wspólnoty podjęcia koniecznych środków w celu zapewnienia bardziej uprzywilejowanego traktowania niż zagwarantowano to krajom trzeciego świata za pomocą klauzuli największego uprzywilejowania na te same produkty.

Dispute Settlement Procedure (9 kwietnia 1999 r.).

WT/DS27/ARB.

Paragraf XIII.174.

Dz.Urz. 2001 L 31/2.WE

Commission MEMO/01/135 (11 kwietnia 2001). 
zostało zarezerwowane dla podmiotów bez takich referencji ${ }^{60}$. Jeżeli chodzi o same kontyngenty, przewidziano trzy rodzaje, ale - zgodnie z nowym artykułem 18 - wszystkie w zasadzie otwarte dla importu ze wszystkich krajów trzecich: kontyngent A na 2,2 miliona ton $\mathrm{z}$ cłem 75 EUR za tonę, kontyngent B na 353 tysięcy ton z tym samym cłem oraz kontyngent $C$ na 850 tys. ton z cłem 300 EUR za tonę. Jednakże ustanowiono preferencję celną w wysokości 300 euro za tonę dla jakiegokolwiek importu z krajów ACP zarówno w ramach kontyngentów, jak i poza nimi, co mogłoby pozwolić na bezcłowy import z krajów ACP w ramach każdego z tych kontyngentów.

Jednak zgodnie z porozumieniem z USA, 100 tys. ton przeniesiono z kontyngentu $\mathrm{C}$ do kontyngentu $\mathrm{B}$, a zmniejszony kontyngent $\mathrm{C}$ został zarezerwowany wyłącznie dla bananów z krajów ACP ${ }^{61}$, co wymaga uzyskania zwolnienia z wymogów ustanowionych artykułem XIII GATT, ale Stany Zjednoczone i Ekwador ${ }^{62}$ obiecały pomóc je uzyskać. Co do dalszej przyszłości, proponowało się wprowadzenie systemu opłat stałych (flat-tariff system) począwszy od roku $2006^{63}$.

W międzyczasie Wspólnota uzyskała zwolnienie z wymogów art. XIII: 1 i 2 GATT na okres od 1 stycznia 2002 r. do 31 grudnia 2005 r., w którym miały być ustalone kontyngenty z krajów ACP. Jednakże - po przejściu przez arbitraż i kolejne nieudane próby rozwiązania tego problemu, jak też wygaśnięcia zwolnienia kwestia dostępu do europejskiego rynku bananów przez kraje ACP oraz inne, przede wszystkim dostawców bananów z państw najbardziej uprzywilejowanych (MFN, Most Favoured Nation) po raz kolejny jest przedmiotem sporu na forum $\mathrm{WTO}^{64}$.

\section{Subwencje eksportowe}

Jeśli (co miało zwykle miejsce w systemie opierającym się na cenie interwencyjnej i docelowej) cena światowa była niższa od wspólnotowej ceny interwencyjnej, a wspólnotowi producenci chcieli eksportować na światowe rynki o niższych cenach, wspólnotowy ustawodawca miał (i nadal ma) prawo do zadecydowania o wypłacie refundacji eksportowych, które pokryją różnicę w cenie ${ }^{65}$.

Wydaje się, że to właśnie system refundacji eksportowych był powodem największej ilości skarg wnoszonych przez handlowych partnerów Wspólnoty. Wskazywano jednak, że system refundacji eksportowych, razem ze zmiennymi opłata-

60 Commission IP/01/628 (2 maja 2001).

61 Commission MEMO/01/135 (11 kwietnia 2001).

62 Commission IP/01/628 (2 maja 2001).

63 Commission MEMO/01/135 (11 kwietnia 2001).

64 Zob. WT/DS27/80 oraz WT/DS361/1.

65 Zob. E. Tomkiewicz w podręczniku pod red. A. Jurcewicz, A. Jurcewicz, B. Kozłowska, E. Tomkiewicz, Wspólna polityka rolna. Zagadnienia prawne, Warszawa 2004, s. 100-101. 
mi wyrównawczymi, został uznany - w wyniku negocjacji z Rundy Villon ${ }^{66}$ - za spójny z GATT. W każdym razie artykuł XVI GATT wymaga od państw członkowskich jedynie, aby „,starały się” (,seek”) unikać stosowania subwencji przy eksporcie produktów podstawowych, ale subwencje eksportowe jako takie nie stanowią naruszenia GATT. Jeżeli jednak Strona przyznaje subwencję, która powoduje zwiększenie eksportu z terytorium tej Strony, subwencja ta nie powinna być stosowana w sposób, który spowoduje, że Strona ta posiądzie „więcej niż sprawiedliwy udział" (,more than an equitable share”) w światowym ekporcie danego produktu w porównaniu z udziałem we wcześniejszym reprezentatywnym okresie. Pojęcie „więcej niż sprawiedliwy udział” zdefiniowano w artykule 10 Subsidies Code, uzgodnionym podczas Rundy Tokijskiej jako „każdy przypadek, w którym skutkiem subwencji przyznanej przez sygnatariusza jest wyparcie eksportu innego sygnatariusza, uwzględniając rozwój wydarzeń na rynkach światowych”.

W tym kontekście Australia i Brazylia złożyły skargę, że wspólnotowe refundacje eksportu cukru doprowadziły do uzyskania przez wspólnotowych eksporterów więcej niż sprawiedliwego udziału w światowym eksporcie cukru67. Panel stwierdził co prawda, że Wspólnota zwiększyła swój udział w rynkach światowych, ale nie można tu wykazać związku z eksportem cukru z Australii i Brazylii, a zatem nie można stwierdzić, że Wspólnota uzyskała taki więcej niż sprawiedliwy udział. Stwierdzono, że wspólnotowe praktyki przyczyniły się do spadku światowych cen cukru, powodując pośrednie szkody skarżącym, ale szkód tych nie da się oszacować. $Z$ drugiej strony, jeszcze przed wejściem w życie CAP, w przypadku wspierania przez Francję eksportu pszenicy i mąki pszennej ${ }^{68}$ przez premie eksportowe (differential bonuses i variable bonuses) stwierdzono, że francuski udział w rynku południowo-wschodniej Azji stał się niesprawiedliwy (inequitable), wzrastając z poziomu $0,7 \%$ w roku 1954 do poziomu $46 \%$ w roku 1958, co w znacznym stopniu było skutkiem tych subwencji.

Następnie Stany Zjednoczone złożyły skargę na wspólnotowe subwencje eksportu mąki pszennej ${ }^{69}$, ale panel orzekł, że - ze względu na sztuczne warunki na tym rynku - nie można stwierdzić, czy Wspólnota uzyskała więcej niż sprawiedliwy udział, czy nie. $Z$ drugiej strony, w kontekście refundacji wypłacanych przy eksporcie makaronu ${ }^{70}$, pomimo iż UE utrzymywała, że są one związane wyłącznie z pszenicą durum zawartą w makaronie, orzeczono, że subwencje na produkty przetwo-

66

Zob. E. Nerville-Rolfe, The Politics of Agriculture in the European Community, Policy Studies Institute, London 1984, s. 26.

Basic Instruments and Selected Documents (BISD) nr 26, supplement 290, nr 27, supplement 69, nr 29 supplement 82.

BISD nr 7, supplement 46 .

Zob. I. Garcia Bercero, Trade Laws, GATT..., op. cit., s. 168.

Ibidem, s. 168-169. 
rzone nie korzystają z takich samych przywilejów co podstawowe produkty rolne, powołując się w szczególności na Subsidies Code.

Porozumienie w sprawie rolnictwa wymaga, aby sygnatariusze redukowali wartość i gamę takich subwencji eksportowych, ale nie wymaga, aby je całkowicie zlikwidowali. Artykuł 3(3) stanowi, że ,zgodnie z ustępami 2(b) i 4 artykułu 9 niniejszego Porozumienia, członkom nie wolno przyznawać subwencji eksportowych określonych ustępem 1 artykułu 9 w odniesieniu do produktów rolnych, bądź grup produktów, określonych... Harmonogramem powyżej poziomu wydatków budżetowych i poziomu ilościowego, do jakich się zobowiązali określonych tamże, jak również nie mogą oni przyznawać takich subwencji w odniesieniu do produktów rolnych nie wymienionych w tej sekcji Harmonogramu". W przypadku WE refundacje eksportowe mają ulec redukcji średnio o 36 procent $\mathrm{w}$ odniesieniu do wartości i o $21 \%$ w odniesieniu do wolumenu w porównaniu z okresem bazowym 1986-1988. Można jednak zauważyć, że przejście z systemu wsparcia produktu (interwencji) do systemu wiążącego się ze wsparciem dla producenta spowodowało automatycznie redukcję kwoty wewnętrznego wsparcia ogólem wyliczaną dla potrzeb WTO oraz - jak wspomniano wcześniej - zredukowało wymagany poziom refundacji eksportowych. Powiedziano już, że rozporządzenie Rady 1253/1999 ${ }^{71}$ stanowi o dalszej redukcji ceny interwencyjnej w latach gospodarczych 2000-2001 i 20012002, antycypując ostateczną redukcję tej ceny w roku gospodarczym 2002-2003. Natomiast rozporządzenie Rady 1251/199972 zwiększa dopłaty bezpośrednie do niektórych upraw rolnych w latach gospodarczych 2000-2001 i 2001-2002, antycypując dalsze podwyżki w związku z ostateczną redukcją ceny interwencyjnej.

W kwestii subwencji eksportowych Porozumienie kładzie nacisk na inne sprawy niż w kwestii wewnętrznego wsparcia. O ile w przypadku wewnętrznego wsparcia Porozumienie bardzo szczegółowo określa rodzaje wsparcia, które nie muszą być zredukowane, o tyle w przypadku subwencji eksportowych Porozumienie bardzo szczegółowo określa rodzaje pomocy finansowej, które muszą ulec redukcji. Subwencje eksportowe podlegające zobowiązaniom w kwestii redukcji określa artykuł 9(1). Są to:

(a) Przyznawane przez rządy lub ich agencje bezpośrednie subwencje (direct subsidies), w tym w naturze, dla firm, zakładów, producentów rolnych, spółdzielni lub stowarzyszeń takich producentów, bądź też dla agencji do spraw handlu, zależne od ich wyników w eksporcie.

(b) Sprzedaż, bądź wyzbycie się, na eksport przez rządy lub ich agencje niesprzedawalnych (non-commercial) zapasów produktów rolnych po cenie 
niższej od porównywalnej ceny na podobne produkty oferowanej nabywcom na rynku wewnętrznym;

(c) Płatności za eksport produktów rolnych finansowane z działań rządowych, bez względu na to, czy obciążają daną pozycję budżetu czy nie, w tym płatności finansowane $\mathrm{z}$ przychodów $\mathrm{z}$ opłat (levies) nałożonych na dany produkt rolny lub na produkt rolny, z którego pochodzi dany produkt eksportowy.

(d) Subwencje wypłacane w celu redukcji kosztów marketingu eksportu produktów rolnych (inne niż szeroko dostępna promocja eksportu i usługi doradcze), w tym kosztów manipulacji produktem, ulepszania i innych kosztów przetwórstwa oraz kosztów międzynarodowego transportu i frachtu.

(e) Opłaty za transport wewnętrzny lub fracht, rządowe, bądź delegowane przez rząd, oferowane międzynarodowej spedycji na bardziej korzystnych warunkach niż wewnętrznej spedycji.

(f) Subwencje dla produktów rolnych zależne od tego, czy produkty te zostaną wyeksportowane.

W przypadku UE, definicja ta zawiera nie tylko refundacje eksportowe jako takie, ale również sprzedaż na eksport nadwyżkowych zapasów interwencyjnych po cenie niższej od ceny na rynku wewnętrznym i refundacje za przetworzone produkty rolne.

Artykuł 9(2) mówi jasno, że poziom zobowiązań w kwestii subwencji eksportowych stanowi na każdy rok okresu wdrożeniowego - w przypadku zobowiązań dotyczących redukcji wydatków budżetowych - maksymalny poziom wydatków budżetowych na subwencje przyznawane lub wypłacane w danym roku oraz - w przypadku zobowiązań dotyczących redukcji wolumenu eksportu - maksymalną ilość danych produktów rolnych bądź grup produktów rolnych, w odniesieniu do których można w danym roku przyznać subwencje eksportowe. Tym niemniej, artykuł 9(2)(b) zezwala na pewne ruchy tych liczb pod warunkiem, że zakumulowana kwota wydatków budżetowych nie przekroczy zakumulowanej kwoty, która powstałaby w wyniku pełnej zgodności z zobowiązaniami co do rocznych wydatków budżetowych określonych w Harmonogramie dla danego członka o więcej niż 3\% poziomu roku bazowego dla danych wydatków budżetowych, a zakumulowany wolumen eksportu nie przekroczy zakumulowanego wolumenu, który powstałby w wyniku pełnej zgodności ze zobowiązaniami w kwestii rocznego wolumenu eksportu określonego w Harmonogramie dla danego członka o więcej niż 1,75\% poziomu roku bazowego. Podlega to ogólnemu zapisowi stanowiącemu, że wydatki budżetowe członków na subwencje eksportowe oraz wolumen eksportu objęty tymi subwencjami na zakończenie okresu wdrożeniowego nie powinny przewyższać od- 
powiednio 64\% i 79\% poziomu z okresu bazowego 1986-1988. Dla państw rozwijających się liczby te wynosiły odpowiednio $76 \%$ i $86 \%$.

Artykuł 10 określa środki służące do obejścia zobowiązań w kwestii subwencji eksportowych. Artykuł 10(1) stanowi, że subwencji eksportowych, których nie wylicza artykuł 9(1), nie wolno stosować w sposób powodujący obejście lub zagrażający spowodowanie obejścia zobowiązań w kwestii subwencji eksportowych. Zobowiązań tych nie wolno również obchodzić przy pomocy niekomercyjnych transakcji. Natomiast artykuł 10(3) stanowi, że członek, który utrzymuje, że eksport powyżej poziomu zobowiązań nie korzystał z żadnych subwencji eksportowych musi dowieść, że za ten wolumen eksportu nie udzielono żadnych subwencji, wyliczonych lub nie wyliczonych w artykule 9. Ciężar dowodu nałożono zatem na eksportera, który musi dowieść, że wyeksportowane ilości produktu, które przekraczają zobowiązania redukcyjne, nie skorzystały z subsydiów wymienionych w art. 9(1). Ponadto dochodzi do tego zobowiązanie, ustanowione artykułem 10(2) do działania na rzecz uzgodnienia na szczeblu międzynarodowym zasad porządku regulującego udzielanie kredytów eksportowych, gwarancji eksportowych i programów ubezpieczeń eksportowych w zgodności z tymże porządkiem.

Artykuł 10(4), przewidując możliwość udzielenia pomocy żywnościowej celem obejścia zobowiązań w kwestii subwencji eksportowych stanowi, że członkowie-darczyńcy ofiarujący międzynarodową pomoc żywnościową winni zapewnić, że udzielanie tej pomocy nie wiąże się, bezpośrednio lub pośrednio, z komercyjnym eksportem produktów rolnych do krajów-beneficjentów, a transakcje dotyczące międzynarodowej pomocy żywnościowej są prowadzone zgodnie z zasadami FAO ("Principles of Surplus Disposal and Consultative Obligation") włączając, gdzie właściwe, system zwykłych wymogów marketingowych (The system of Usual Marketing Requirements - UMR) oraz że pomocy tej udzielą całkowicie nieodpłatnie w możliwym zakresie lub na rygorystycznych warunkach określonych artykułem IV Konwencji w sprawie pomocy żywnościowej z 1986 r. (Food Aid Convention 1986).

W odniesieniu do produktów przetworzonych artykuł 11 deklaruje, że w żadnym wypadku subwencja na jednostkę produktu wypłacana za włączony doń produkt podstawowy nie może przekroczyć subwencji na jednostkę, która zostałaby wypłacona za eksport tego produktu podstawowego.

\section{Status WTO/GATT we wspólnotowym prawie}

Z przedstawionej powyżej treści Porozumienia w sprawie rolnictwa jasno wynika istnienie znaczącej interakcji pomiędzy warunkami Porozumienia a ewolucją organizacji rynków rolnych. Polityka Wspólnoty w tym zakresie nie oparła się na stanowisku nieustannie reprezentowanym przez Europejski Trybunał Sprawiedliwo- 
ści, że zapisy GATT/WTO nie są władne wywierać bezpośredniego skutku. Pomimo że przed Porozumieniem Rundy Urugwajskiej Trybunał oświadczył, że Wspólnota zastąpiła państwa członkowskie Wspólnoty w ramach GATT ${ }^{73}$, zapisy GATT są wiążące dla Wspólnoty, a od chwili wejścia w życie Wspólnej Taryfy Celnej dnia 1 czerwca 1968 GATT należy traktować jak wspólnotowy akt prawny dla celów interpretacji ${ }^{74}$, to jednak orzekł, że ogólna struktura Porozumienia, które charakteryzuje się elastycznością i możliwością uzyskania derogacji powoduje, że jego zapisy nie mogą być podstawą praw egzekwowalnych przed sądami krajowymi. Zatem nie można się do nich odwołać jako do dziedziny prawa wspólnotowego, aby zakwestionować ważność ustawodawstwa krajowego ${ }^{75}$. Jeszcze bardziej interesujące jest to, że we wcześniejszym orzeczeniu ${ }^{76}$ Trybunał orzekł, że do zapisów GATT nie można się odwołać, aby zakwestionować ważność ustawodawstwa wspólnotowego, chyba że można udowodnić, że zapisy te mają bezpośredni skutek. O ile pojęcie skutku bezpośredniego nie wydaje się istotne w przypadku powództwa o unieważnienie wspólnotowego aktu prawnego wniesionego przez państwo członkowskie będące jako takie stroną GATT, w odniesieniu do tego powództwa ${ }^{77}$ Trybunał orzekł, że jedynie w przypadku, gdyby to Wspólnota zamierzała zrealizować konkretne zobowiązanie włączone do zakresu GATT lub gdyby to wspólnotowy akt prawny odnosił się expresis verbis do konkretnego zapisu GATT ${ }^{78}$, Trybunał zbadałby legalność omawianego wspólnotowego aktu prawnego z punktu widzenia zasad GATT.

Podejście takie Trybunał utrzymał także po podpisaniu Porozumień Rundy Urugwajskiej $^{79}$. W sprawie C-307/99 OGT Fruchthandelgesellschaft v. HZA Hamburg-St Annen ${ }^{80}$ Trybunał orzekł, że handlowcy nie mogą zakwestionować legalności wspólnej organizacji rynku bananów określonej znowelizowanym rozporządzeniem 404/93 ${ }^{81}$ w oparciu o zapisy artykułów 1 i XIII GATT 1994, pomimo że panel WTO w sprawozdaniu z 12 kwietnia 1999 stwierdził, że znowelizowana wersja rozporządzenia narusza te zapisy. Trybunał powtórzył, że Porozumienie WTO, jak również porozumienia i aneksy doń dołączone, ,nie są z zasady wśród zasad, w świetle których Trybunał bada legalność środków przyjmowanych przez wspólnotowe instytucje" dodając, że rozporządzenie 404/93 w znowelizowanej wersji nie

Sprawy nr 21-24/72 International Fruit Co NV kontra Produktschap voor Groenten en Fruit, ECR 1972, s. 1219; sprawa nr 38/75 Duaneagent der NV Nederlandse Spoorwegen kontra Inspecteur der Invoerrechten en Accijnzen, ECR 1975, s. 1439; sprawy nr 267-269/81 Amministrazione delle Finanze dello Stato kontra SPI, ECR 1983, s. 801.

Zob. M. Sztąborowska, Wspólnoty Europejskie w Światowej Organizacji Handlu - aspekty prawne, Wspólnoty Europejskie 2005, nr 5, s. 15-19.

Zob. sprawa powołana w przypisie 73 Amministrazione...

Zob. sprawa powołana w przypisie 73 International Fruit...

Sprawa nr C-280/93 Germany kontra Council, ECR 1994, I-4973.

Sprawa nr C-70/87 Fediol, ECR 1989, s. 1781; sprawa nr C-69/89 Nakajima kontra Council, ECR 1991, I2069.

79 Sprawa nr C-149/96 Portugal kontra Council, ECR 1999, I-8395.

802 maja $2001 \mathrm{r}$.

81 Dz.Urz. WE 1993 L 47/1. 
miało na celu zapewnienia realizacji przez porządek prawny Wspólnoty konkretnych zobowiązań powziętych w ramach GATT i nie odnosiło się ono expresis verbis do zapisów GATT.

Rozpatrując tę sprawę w szerszym kontekście, warto wspomnieć o amerykańskim akcie prawnym Urugway Trade Agreements Act 1994, który w sekcji 102(a)(1) stanowi, że „żadne zapisy Porozumień Rundy Urugwajskiej niespójne z prawem Stanów Zjednoczonych, ani wykonywanie tych zapisów wobec osób lub okoliczności nie może mieć skutków, a sekcja 102(b)(2)(A) deklaruje, że „żaden przepis stanowy, ani jego stosowanie wobec osób lub okoliczności nie może zostać uznany za nielegalny w oparciu o to, że przepis ten lub jego wykonywanie nie jest spójne z Porozumieniami Rundy Urugwajskiej”, o ile nie zostanie on zaskarżony przez władze federalne. Zatem wykorzystanie zapisów Porozumień jako kryteriów legalności przez handlowców wydaje się całkowicie wykluczone w Stanach Zjednoczonych. Tym niemniej, nie można nie doceniać wpływu Porozumień Rundy Urugwajskiej w kontekście politycznym. 


\section{Agriculture in the context of international agreements}

\section{Summary}

Agriculture is an area where the trade of developed countries appears to be conducted on a highly artificial basis reflecting the system of support used in their internal markets. The reality is that agricultural trade is an area where developed countries have not been willing to allow free reign to market forces. Agricultural trade has always received special treatment in the GATT context.

The Uruguay Round was a historic achievement with respect to agriculture, as it was in so many other areas. The Agreement on Agriculture, which considerably strengthened the GATT rules on agriculture, was designed to shape the future agricultural policies of the members of the newly created World Trade Organization. The Punta del Este Declaration, which launched the negotiations, had set ambitious objectives and substantial progress was made during the negotiations towards realization of those objectives. It must be recognized, however, that the Agreement is only the first step in a process of reform. The reform programme envisaged the adoption of specific commitments to increase market access and to reduce domestic support and export subsidies, which would lead to "substantial reductions in agricultural support and protection sustained over an agreed period of time". 